\title{
Interpreting Gamification via Game Elements: Black Mirror
}

\author{
Bayındır B. ${ }^{1}$ \\ Karadağ G. H. ${ }^{2}$
}

\author{
${ }^{1}$ Berkan BAYINDIR, İstanbul Aydın University (Türkiye) \\ e-mail: berkanbayindir@stu.aydin.edu.tr \\ ${ }^{2}$ Gökmen H. KARADAĞ, İstanbul Aydın University (Türkiye) \\ e-mail: gokmenkaradag@aydin.edu.tr
}

\begin{abstract}
Game, which takes place in humans' life from the beginning of their childhood, turns out to have less importance in daily life as humans get older. However, the need for game exists throughout every period of life. In line with this need, we come across with the gamification concept which is gained by adding game mechanics and dynamics to the non-game environments. Development of internet and digital technologies make it easier to use gamification in different fields. In this study; to what extend gamification will take place in our lives is going to be evaluated and, in this context, an interpretation about the future of gamification will be given. In addition, the game mechanics and dynamics used in the third season's first episode of "Black Mirror" series, which presents a futuristic point of view about how digitalization will affect our future, is going to be evaluated with content analysis technique.
\end{abstract}

Keywords: Game, Gamification, Game Elements, Black Mirror, Social Scoring.

\section{Introduction}

Human is a social entity that lives as a member of a community. It is accepted that there are different reasons in this way of living style. When humans are in a society they are more successful at struggling with nature, the need for communicating is an indispensible part of life, internalizing the culture of one's own society and transferring this culture to new generations, satisfying the need for security is more easier when a human belongs to a community, can be indicated as some of the reasons which come into mind at first (Güngör, 2016: 17-40; Tutar and Yılmaz, 2010: 16-19; Çağlar and Kılıç, 2011: 4). New generations adopt themselves to their communities by observing adults and pretending their behaviours. In order to complete the adaptation period probably game is the most important tool that children can use. Game is a phenomenon which helps children to gain abilities they will possibly need in the future, explore their abilities and pursuits, and improve their communication skills. However, the thought of game notion belongs to children or childhood can be illusory. The main reason of this illusion is in the meaning of being serious which is matched with adulthood and business life. We also come across this perception in daily life with the saying 'we are not playing game here!' This saying also highlights games cannot be serious. In contrary, thinkers and academicians explain that game is a phenomenon which is done in a serious manner (Adler, 2012: 83; And, 2012: 28; Erkek, 1999: 1; Huizinga, 2017; Oskay, 2014: 224). To relax or get away from the hustle and bustle of daily life, it is a fact that sometimes adults also play or watch some kind of games.

Johan Huizinga explained how games are important for humans in their daily life in his book "Homo Ludens" (2017). Huizinga searched the relations between games and many other fields of life ranging from culture to the religious ceremonies and in this context his work has become a mile stone for the field of game researches. Since recalling the importance of games in humans' life, some affords have been done to use games in different fields like education, business, management, and health (Bayraktar, 2015; Yılmaz, 2018). In line with this, gamification is another notion which is discussed and thought about. Adding game mechanics, dynamics, and using game design techniques in non-game contents in order to solve problems or increase brand loyalty is called gamification (Deterding et al., 2011: 9; Yılmaz, 2017: 19). The purpose of gamification is to increase the humans' 
participation level to an event or a subject. The main aim is to get the individuals participate in this process with their intrinsic motivation. After the term was first used in 2002, gamified applications became a current issue in 2010. It can be assumed that more researches will be done on the subject in the following years and gamification will be on the agenda more often. Today gamification notion is mostly seen in the fields like education, health, marketing, management, and brand loyalty.

The assumption of this study is gamification, which has been used in different fields, will be used more widely in daily life in the future. From this point of view, this study is limited with the third season's first episode of 'Black Mirror' series named as 'Nose Dive' and broadcasted digitally by Netflix. The episode is important for predicting the future of gamification notion as it gives a futuristic point of view on how game mechanics and dynamics can be used in ordinary course of life. The game components, mechanics, and dynamics which are used in the episode are going to be determined with content analysis method and a vision about the future of gamification is going to be stated at the end of this study.

\section{Game Notion and Its Definition}

In the $21^{\text {st }}$ century internet and digital technologies have been developed and they have turned out to be the indispensable parts of our lives. Being related to this transformation games have become digitalized. Especially for the new generations, who are also called as digital natives, the word 'game' is associated with games which can be played on computers or mobile devices. In this context, for digital natives' game is something which is mostly played digitally. However, every generation has its own popular games and some of them are still being played today. Different researches have proved that some games, which are still being played in today's time, have been existed for a long time. In picture 1, the board game called 'Senet' is being played by Queen Nefretity (Juul, 2005:4).

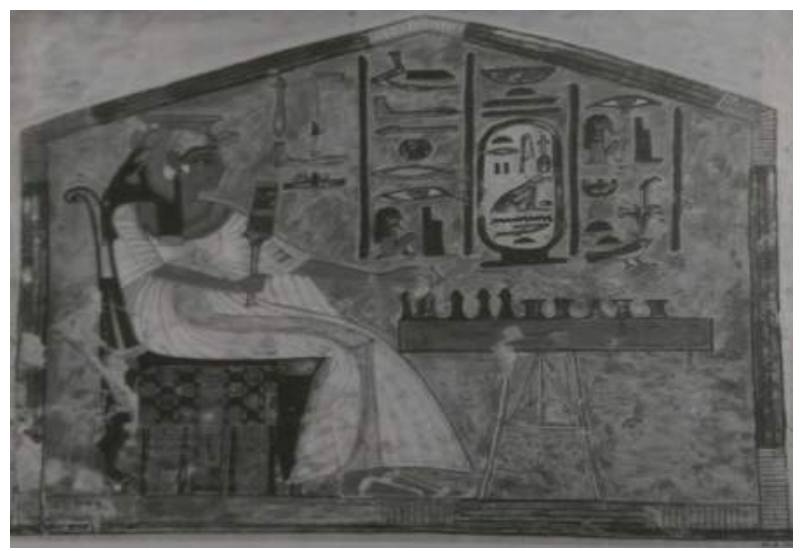

Picture 1. Queen Nefretiry is playing the board game "Senet". Reference: (Juul, 2005:4)

Game is not an activity only played by children and it can be said that its history is as old as the human's history. "In archaeological excavations held in Egypt and Iran toys were found, in ancient Cretan civilization ruins some baby dolls and domestic toy utensils were found" (Akandere, 2013: 4). Game is an irresistible activity especially for the kids but at the same time it is also considered as a break from the daily life for the adults. As Metin and mentions; "Game is a break in daily life, a rest, an ornament of daily life" (2012: 28). It is necessary to mention the prominent features of this activity by giving the definitions of thinkers and academicians.

\section{Definition of Game within Its General Features}

Different thinkers and academicians have done researches on game. The place of game in humans' life was stated with "Homo Ludens" by Johan Huizinga. According to him; humans are not "Homo Saphiens" which means wise beings or "Homo Faber" which means a tool maker, moreover human is a being who plays games. Huizinga defines game as "an activity which occurs in certain place, time, and willpower borders, within apparent regular orders, obeying to the rules with free will, and belonging to a field out of financial benefits and necessities"(2017:181). As it is understood from 
the definition, game occurs in its own place and time circumscription. The individual participates in it with his/her freewill and obeys the rules of the game. The necessities of the real life stay out of the game zone.

Roger Caillois defines game with six features. These are being free, separate, uncertain, unproductive, governed by rules, and make-believe (Caillois, 2001: 9-10). Following Huizinga, Caillois added uncertainty and make-believe to his definition. Uncertainty explains that the result of the game keeps its mystery at the beginning. It highlights the thought that if the result is known from the beginning the activity is not considered as a game. Make-believe points out that the participants fulfil their activity faithfully.

Schiller states that "humans play in where they exist and they will be complete humans when they play" (Erkek, 1999: 1). In Schiller's statement it is clearly mentioned that games take an important place in human's life and it is one of the fundamentals of being a human. Even though Schiller places the game in the centre of human life when our environment is observed we can see behaviours which look similar to playing game among animal species. Especially while cubs are scuffling, they both gain the hunting abilities which they will need in the future and they also participate in some kind of a socialization process. The lion cubs we watched on documentaries or the kittens we can easily see in streets in our daily life are good examples of this kind of behaviours. Evaluating this kind of behaviour as a play among these cubs is because they do not hurt each other while they are scuffling. Also children socialize and get ready to learn the norms of their society while they are playing. Yalçınkaya states that the existing social relationships and also the community conscious are the notions which are reached as a result of humans' historical improvements (2004: 19). Throughout pre-school period game is a helpful activity which informs the child about the world s/he is living in, teaches the social relationships among his/her peers and makes the child recognize his/her limitations (Yalçınkaya, 2004:59).

In general game is defined as an activity which has uncertain result, the individual participates for pleasure more than an aim and it is maintained without a productive outcome by means of economy (Doğan, 2013: 20). Philosophers like Nietzche, Heidegger, Gadamer etc. explaines that game is consisted of repeated actions in a cyclic motion. Due to this cyclic motion game is sometimes thought as a circle, a wheel or a ring. It is seen that some efforts are done in different studies to classify games. Nevertheless, a uniform game classification has not been done.

\section{Caillois' Game Classification}

Thinkers and academicians, who analyze or define game, have developed different approaches to the notion according to their perceptions. Generally, the descriptions complete each other or make some additions. In this context, although the common features are presented by different words, they do not separate from each other totally. But it is not possible to state the same comment about the classification of games. The main reason of these different classifications is it is possible to group games under more than one title and there is not a general classification which has been agreed on. While categorizing games, the perception and point of view of the researcher or thinker is effective. Caillois' classification is given as an example in this study due to its being a reference in the field of game research.

In his classification Caillois divided games into four main categories. They are determined as 'agôn' in means of competition, 'alea' represents chance, 'mimicry' defines simulation, and 'ilinx' states vertigo. Another two sub-categories are added to these four and they are named as 'paida' which describes spontaneous play and 'ludus' is used for describing controlled play (Caillois, 2001: 12-13). 


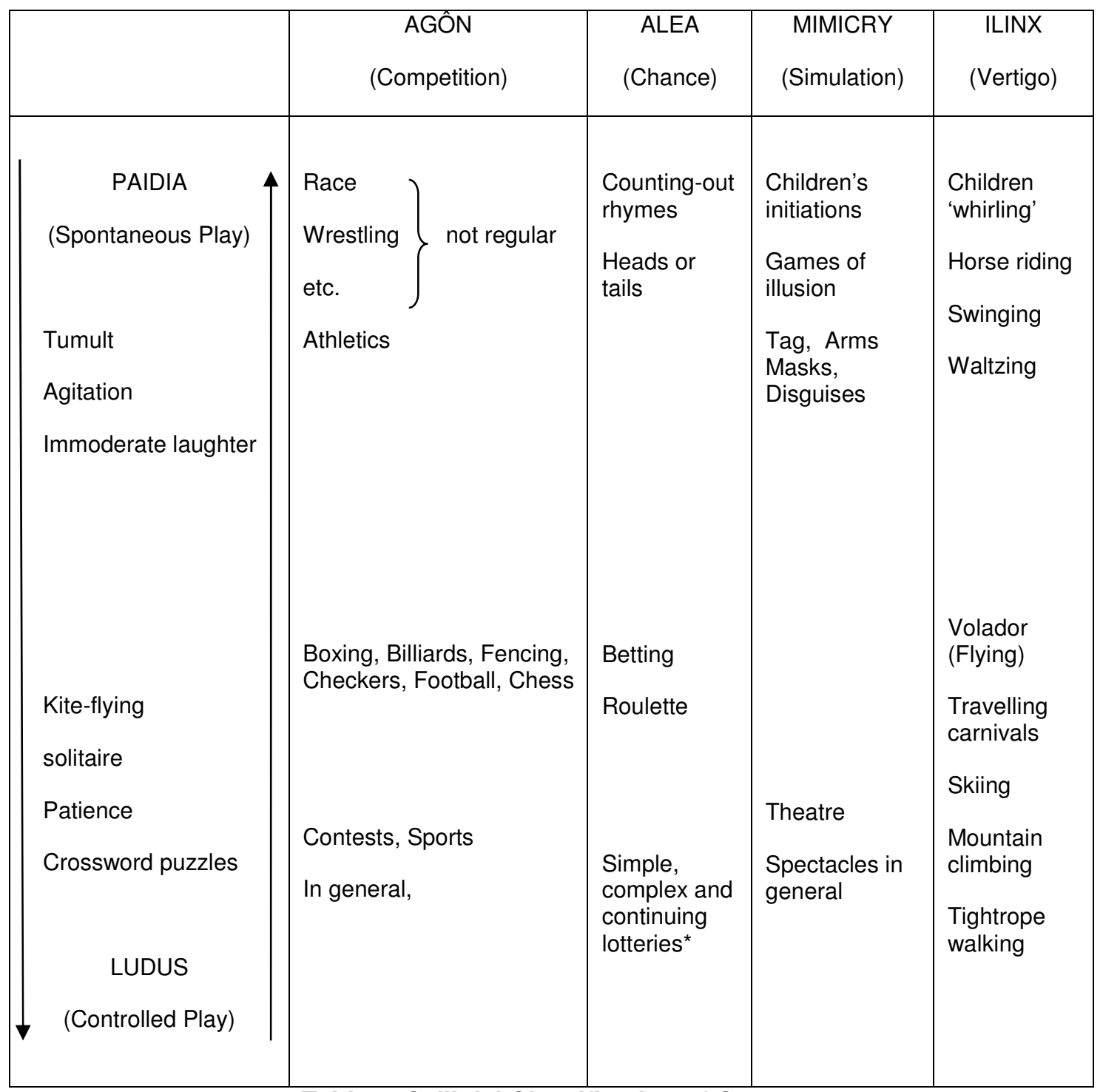

Table 1. Caillois' Classification of Games

(Caillois, 2001: 36)

In Caillois' classification as seen in Table 1, the categories are classified as competition, chance, simulation, and vertigo. The games which are included in the classification are rated from spontaneous to the controlled ones. Paidia represents spontaneous fantasy games whereas ludus states games which have a winner and a loser at the end of each game (Yengin, 2012: 96). From paida to ludus the games, which are irregular, noisy and improvised, are turned into more controlled ones and rules become dominant.

The difference between simple, complex and continuing lotteries is emphasized with the sign $\left({ }^{*}\right)$ in the table and explained by Caillois as follows: Simple games of chance (alea) are resulted with only one draw. The complex ones are the draws which have many possible combinations. Continuing lotteries are consisted of two or more stages. The winner of the first stage is granted to enter the next stage. Both in definitions given in this study and in Caillois' classification, it is seen that the game notion takes place in human's life from the beginning of childhood with different formations. It is necessary for the individual to participate in the game activity, which has an important place in human's life, voluntarily obey the rules and continue the process while also having pleasure from the activity. In this context in order to engage individuals to non-game situations and environments with the same intrinsic motivation as in games, game mechanics and dynamics are added to have game 
like features in non-game situations and environments. With this approach an individual, who does a duty or represents expected behaviours, participates in the process with his/her intrinsic motivation.

\section{Definition of Gamification Notion}

Humans' interest in games from their childhood and some cub kinds showing playful behaviours has taken the attention of thinkers and researches who are interested in the subject. The thought of using game elements in different fields evoked due to game notion has an important place in humans' life and subjectively people show positive attitudes while they are playing. Gamification notion took the advantage of games having been developed in historical timeline process. (Bayraktar, 2015: 17). The advantages of digital communication and game industry play an important role in the development of gamification. "Even though game is regarded as a humanistic instinct and one of the components of mankind, in different eras the definition of game has changed and game notion has taken different roles in our lives" (Sezgin et.al., 2018: 170). Besides their important potentials, games' being digitalized has an effect on players' playing styles (Yılmaz, 2018: 20). In this context, to increase the participants' engagement and internalize the process is aimed by adding structure and design patterns like game mechanics, dynamics, and components to the non-game environments or situations. The word 'gamification' was first used by Nick Pelling, who is also a computer game designer; in 2002 therefore he is accepted as the name father of the notion (Burke, 2014: 5). The notion did not get enough attention at first but it was mentioned in Gartner Hype Cycle in 2009 and got a rise in Google Trend List in 2010.

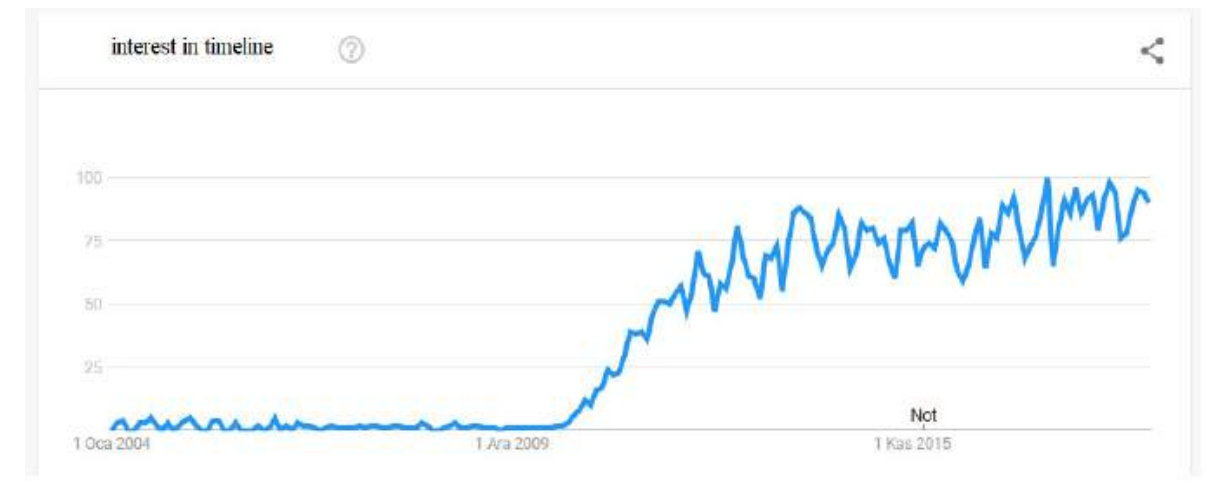

Figure 1. Result Graphic of the Word 'Gamification' in Google Trends

("Gamification," n.d.)

The internet site 'Gamified UK' explains gamification as making game like experiences in nongame contents and it also points out the word gamification is used as a noun ("Gamification," n.d.). According to Niels van der Linden; the approach which targets a long term behavioural changes in participants and tries to solve motivational problems in real life by using game design techniques, is called as gamification (YIlmaz, 2017: 19). The environments which are designed in line with the game thought will attract the users' attention and their intrinsic motivation will be increased is the assumption of gamification. In line with this assumption, it is said that the $75 \%$ of gamification is psychological and $25 \%$ of it is technological (Yılmaz, 2017: 22). Gamification is mostly related with human psychology thus it is necessary to behave proper to ethic rules during its design process. Since gamification is a powerful tool in changing human behaviours, it is regarded as some kind of a manipulation by most of the people (Marczewski, 2017: 56). A gamified system, like the 'Sesame Credit', which Chinese government is planning to make it mandatory in 2020 , can affect the whole society and may turn the society into a mono-type society. Gamification is defined as using game elements in non-game contents to change people's behaviours therefore the notion of ethics becomes important in this context.

Burke states; to engage and motivate people, every activity which uses badges, points, levels, and leader boards is regarded as gamification (2014:3). On the other hand a successful gamification does not occur only by adding mechanics and dynamics which are commonly used. According to some researches, adding these mechanics and dynamics do not bring an exact success furthermore it sometimes results in failure (Armstrong \& Landers, 2018: 2). The elements proper to the target must 
be identified and selected with care. There is not a unique gamification model which can be applied to all organizations (Kamasheva et.al, 2015: 79). In this context, game components, mechanics and dynamics need to be analyzed.

\section{Game Components, Mechanics, and Dynamics}

When deciding which elements are going to be used in gamification, it is important to select the proper design and structure patterns suitable for the content and aim after the necessary analyzes done at the beginning of the process. Just adding patterns like points, avatars or badges etc. is not enough for a successful gamification. As many people think gamification is at least a kind of manipulation (Marczewski, 2017: 56). In gamification the aim is to engage the participant with his/her intrinsic motivation and due to this reality, it is related with human psychology. In order to clarify gamification; components, mechanics, and dynamics which constitute the notion needs to be explained. Werbach and Hunter modelled game elements with a three pieced pyramid (2012). In their model dynamics are shown at the top, mechanics are seen in the middle, and the components are placed at the bottom of the pyramid.

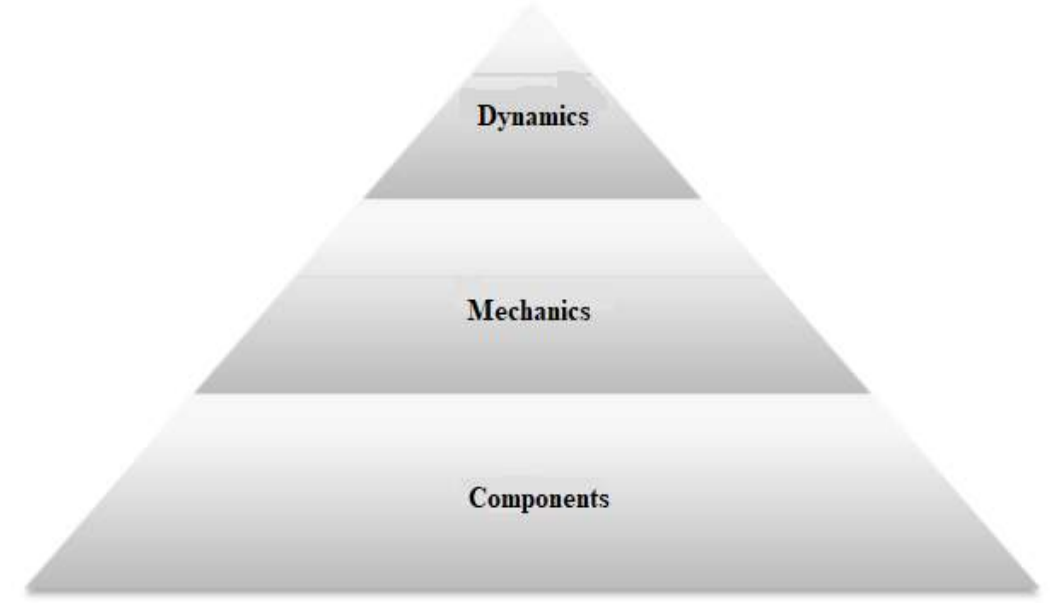

Figure 2. Game Elements Hierarchy

(Werbach and Hunter, 2012)

In figure 2; the game elements are modelled by dynamics, mechanics, and components in a three sectional pyramid shape. The components placed at the bottom are formed by concrete elements; the dynamics at the top are regarded as notional. While gamifiying a content and adding game elements to the process, starting from dynamics and going down to the components is advised. Selecting the appropriate mechanics for the desired dynamics is important for the gamification process. Otherwise the mechanics will lose their efficiency after awhile and the intrinsic motivation which is desired from the participant will fade away. In the literature it is observed that there is an agreement on dynamics but the distinction between mechanics and components is not clear. The working scheme of the system from dynamics to the components and how the distinction between components and mechanics is taken into consideration in this study is clarified according to the explanations given below.

Components: These are the concrete elements or the necessary software which are needed to start the process. Components are the bottom section of the pyramid and they are the fundamental materials for the continuation of the process. For an application which you can join via a mobile phone, a phone, internet connection, etc. are the examples of components. In a sense they can be named as the necessary materials needed for the construction. If cooking a meal is given as an example to clarify the distinction between components, mechanics, and dynamics; the ingredients which are needed for the meal can be called as components. To start cooking a meal first of all you need to have all the necessary ingredients.

Mechanics: They are the steps which provide you reach the dynamics. They are visual and predictable elements. Points, badges, avatars, leader boards, levels, progress bars, etc. are examples 
which are used in many applications. For instance, in order to get the status dynamic, a certain amount of points or some badges must be collected. When cooking example given again, if the ingredients which are accepted as components are ready, the cooking process itself can be mentioned as the mechanics.

Dynamics: They are the final aim for a participant or a player and they cannot be seen during the process. The functionality of the mechanics serves reaching to the dynamics. The dynamics, which are placed at the top of the pyramid, are the source of motivation and they form the main key element of gamification process. Success, expressing oneself, status, cooperation, etc. can be given as examples of dynamics.

When we return back to the cooking example once more, for a delicious meal first of all the ingredients which are accepted as components must be consummate. If one of the ingredients is missing, the taste of the meal will not be good or it will totally be tasteless. The second stage is the cooking process. During cooking process, it is important to use the ingredients in the right order and obey the recipe. In gamification process the equivalent of cooking process is determining the right mechanics and serving them in the right circumstances to the participants. With consummate ingredients and obeying the recipe, the final result is the desired taste of the meal. If one of the components is missing, the player or participant cannot start or join the process. If the components are complete but the mechanics are chosen wrong or given to the player or participant in wrong circumstances, this time the participant or player will leave the process after some time. In this context, the formation of dynamics depends on consummate components, right chosen and motivating mechanics. With this given example, how the distinction between components and mechanics clarified in this study is explained.

\section{Findings}

The universe of the study is chosen from 'Black Mirror' series which was on air in 2011 on a digital platform called Netflix. The main reason of the chosen universe is series' having a futuristic view and some of its episodes are related with the future of gamification. The universe is limited and exemplified with third season's first episode of the series titled as 'Nose Dive'. The episode's plot is about game mechanics and dynamics and how social life is gamified so these are the main reasons of choosing the episode as a sampling for this study. The study is going to be conducted with content analysis method. "Content analysis is mainly analyzing the written, oral (film shootages or photo shootings), visual or recorded documents" (Erdoğan, 2003: 197). Content analysis can also be used as conventional, descriptive (determining the existing) format (Atabek \& Atabek, 2007: 22). In this context, game elements are going to be determined and classified in the aforementioned episode. In the conclusion part the future of gamification is going to be interpreted via analyzed episode. In line with this aim it is assumed that gamification can be used gradually widespread in social life.

Internet and digital platforms depending on it are changing humans' daily life experiences. "New technologies, which have digitalization in the core, have eliminated the limitation of using communication technology for different purposes" (Özel, \& Sert, 2015: 7). The advantages of carrying communication devices in our pockets or bags easily and thanks to internet, these devices allow us use them for different purposes besides from communicating via speaking (Bayındır, 2017: 37). Technology has transformed the daily life by serving more and more opportunities to connect people (Chayko, 2017: 3-4). "Especially the youth in rich countries cannot even imagine a world without mobile services, internet and Facebook or other social sites" (Dijk, 2016: 12).

In the years before 2000's, the watching activity was accomplishable via television. The audience could only watch the series $s / h e$ wanted via television channel and generally once in a week. After movies and series have been broadcasted via digital platforms, the audience's behaviours have started to change. With the invention of every new communication device (media), the effect of the new device on society and individuals becomes a subject of different researches and interpretations (Oktay, 2002: 44). The audience got the advantage of watching the broadcast wherever, whenever and as much as they like. New concepts have existed in our lives with these digital platforms. 'Binge Watching', which means watching a lot of episodes at a time, is one of them. 
Sampling of this study is limited with 'Black Mirror' series first episode of the third season titled as 'Nose Dive'. The study is going to be formed with categories of game elements hierarchy pyramid and the aforementioned episode is going to be analyzed and exemplified in accordance to these categories. When the literature is searched, it is understood that there is not a clear distinction between game components and mechanics. In this study the components are regarded as the necessary elements which let the participant use the application. On the other hand the mechanics are considered as the elements which engage the participant to the process and make him/her continue the process. As it is mentioned before, the ingredients are the necessary materials which means the components and the recipe and instructions of cooking process defines the mechanics. Also the final taste of the meal defines the dynamics which cannot be seen during the process. In this context, the following components, mechanics, and dynamics are determined in the Black Mirror's third season first episode titled as 'Nose Dive'.

\begin{tabular}{|c|c|c|}
\hline Components & Mechanics & Dynamics \\
\hline \multirow{2}{*}{ Lens } & Stars & \\
Score & \\
Lobile phone & Discount & \\
Computer & Reward & Status \\
Social Network & Limitation & Privileged living \\
Internet connection & Interactivity & \\
& Good manners & \\
& Content sharing & \\
& Joining the social & \\
& network & \\
\hline
\end{tabular}

\section{Table 2. Analysis of Black Mirror's 'Nose Dive' Episode According to Game Elements Hierarchy}

Black Mirror series third season's first episode's plot is about events happening around Lacie Pound who is the main character. Lacie tries to increase her score, move to a better neighbourhood and reach the life which high graded people have. In this context, 'Nose Dive' episode looks similar to the gamified system which is being used as a pilot application in some regions of China. The YouTube video named as Propaganda Games: Sesame Credit draws attention to this system's drawbacks (Extra Credits, 2015). The social credit system is based on tracing how good Chinese are as citizens by evaluating their behaviours with points and it is predicted to be mandatory in 2020 (Marczewski, 2017: 58). Roger Creemer, who studies on Chinese law and media at Oxford University, states that in order to evaluate the citizens' behaviours from different perspectives the government wants to build a platform which supports big data, mobile internet and cloud informatics (Huang, 2015).

After content analyze, the elements gathered under three categories in table two. While deciding the distinction between game components and mechanics, the aforementioned explanation has taken into consideration. In 'Nose Dive' episode all the participants live in a fictionalized place and time and they all participate in a scoring system. Five components are determined in the system. The individuals are using lenses in order to get information about others they come across. Individuals score other people they interact with by using their mobile phones. Also they try to increase their own 
scores by sharing content via their mobile phones and computers. To carry out these actions the other two needed components are internet connection and social network access.

Eleven game mechanics are determined in the episode which is about the events happening in Lacie Pound's life. People score others with stars when they communicate or follow them and these stars are turned into points. The collected score gives some advantages to the individuals at all phases of life, like the house they can rent or the place where they can work. On the other side the lower scores cause a limitation on some social facilities or even worse because of low scores one cannot experience some them.

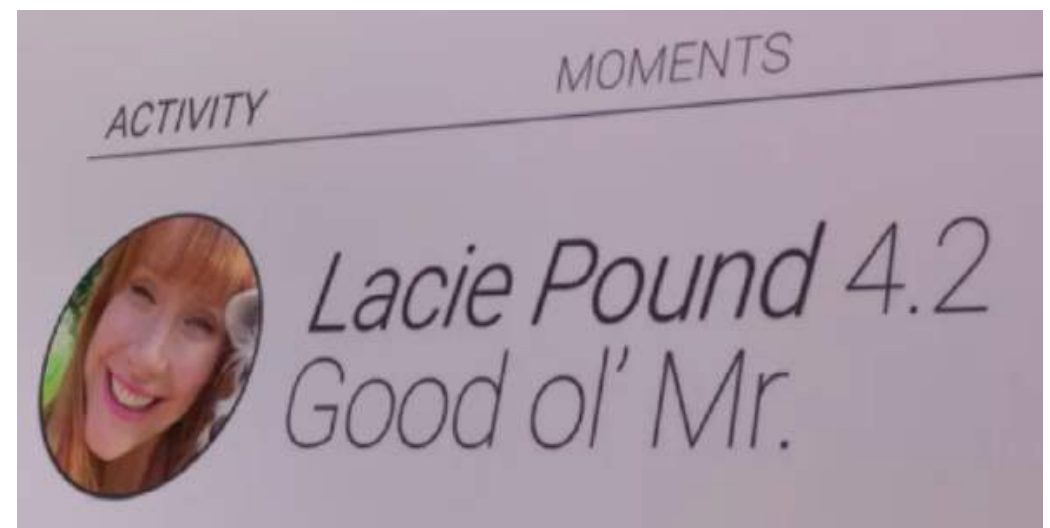

Picture 2. A Sample Scene from Black Mirror's 'Nose Dive' Episode Showing Lacie Pound's Score

In picture 2, it is seen that the scoring system works between points zero to five. In this system scores 4.5 or higher also represents a status and having high scores is a game mechanic which is desired by individuals. For instance, higher scores provide discount while renting a house but lower scores brings some restrictions from various social facilities as a kind of punishment. In this context, the scoring system in the episode looks similar to the 'Sesame Credit' which China wants to apply it in the whole country. Throughout the entire episode Lacie tries to share favourable content and have good relationship with the people she interacts to increase her score. By doing so she hopes to get the chance to rent a house in a province she wants to live in so that she would change her social environment. Privileged life style and status are the game dynamics determined in the episode 'Nose Dive'.

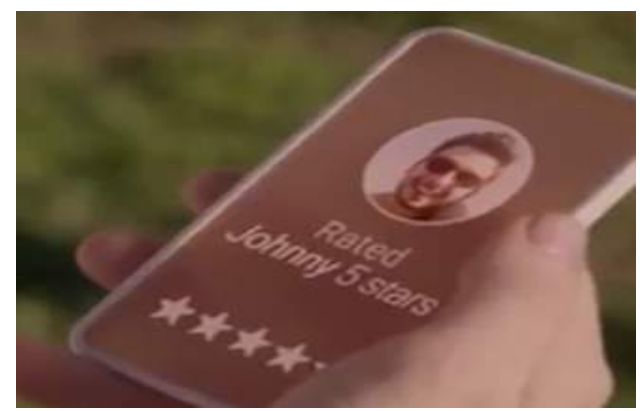

Picture 3. A Scene from Black Mirror's 'Nose Dive' Episode about Scoring Social Media Shares

In the episode the performers use a platform similar to the ones we are using as social media platforms today like Facebook, Instagram, and Twitter. They rate and score other people they interact with by using stars. "Communication network is defined as; the communication devices making connections with each other or their providing cooperation or coordination" (Parlatır et.al., 1988: 1068). In the same way we also share content on social media, send likes about shared contents which are uploaded by our friends or make comments on them. Communication networks are a very common way of communication because every individual in a society is connected to one of these networks physically (Mutlu, 1995:169). 


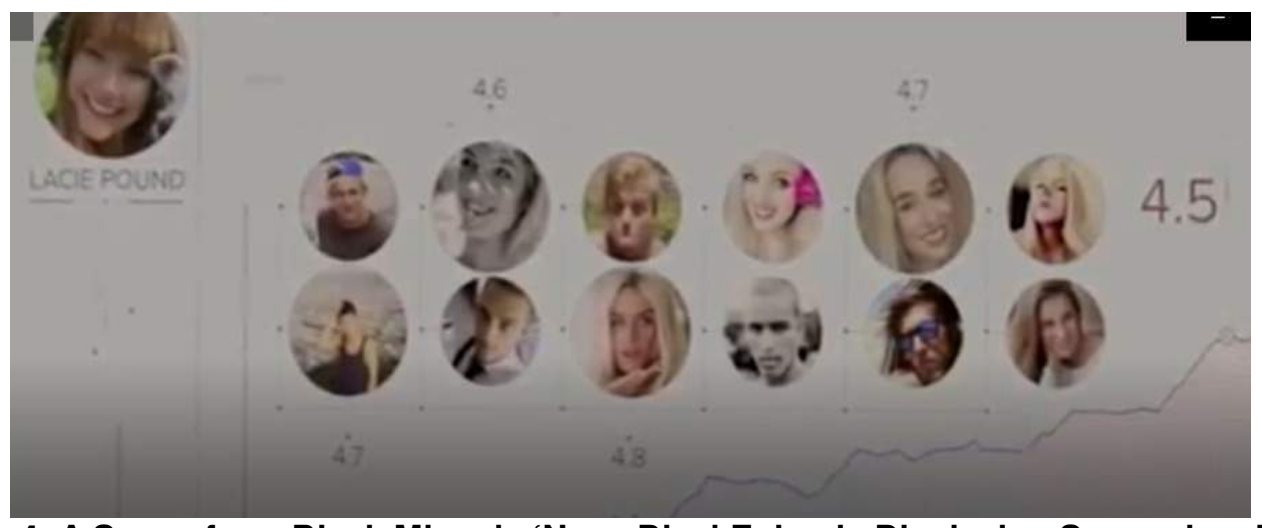

\section{Picture 4. A Scene from Black Mirror's ‘Nose Dive’ Episode Displaying Scores in a Leader} Board

Lacie and others can see on the spot scores of people they are interested in. Leader boards are used as tool for intrinsic motivation and rate the desired targets' proximity. At the same time one can follow the shared content of the people s/he is interested in and can be informed about the hobbies and changes in their lives. While the social media networks serve a similar experience to us, they also collect information about people who share content and form the big data. We do not have the control of the digital data, which is about us and defines us and we do not also have the digital rights of the content we share (Chayko, 2018: 220).

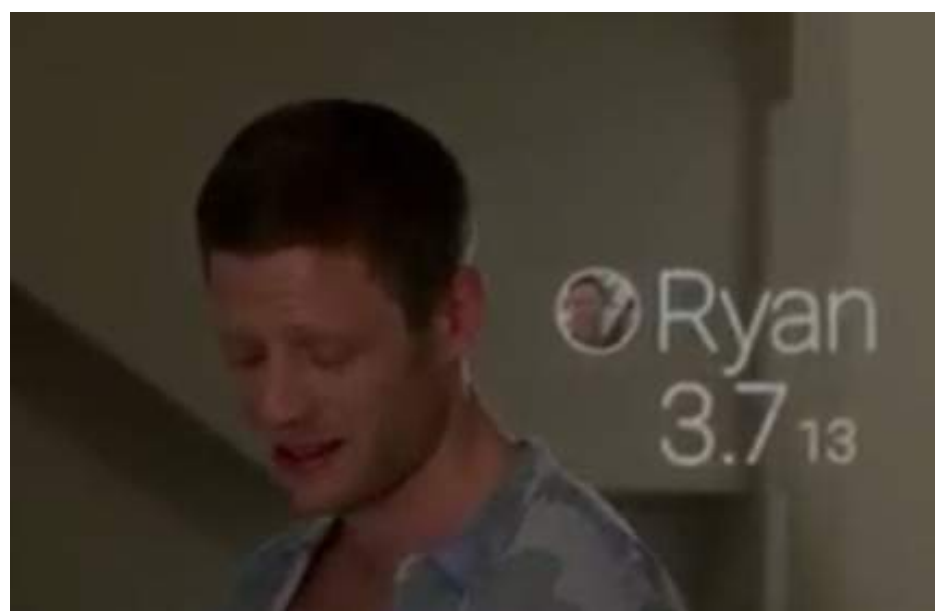

Picture 5. A Scene from Black Mirror's 'Nose Dive' Episode Displaying Getting Information via the Lens

In the episode, the lenses used by the individuals are one of the components of gamification design. The lenses also interact with mobile phones and they can inform the users about instant scores and shared contents of people they interact with. 


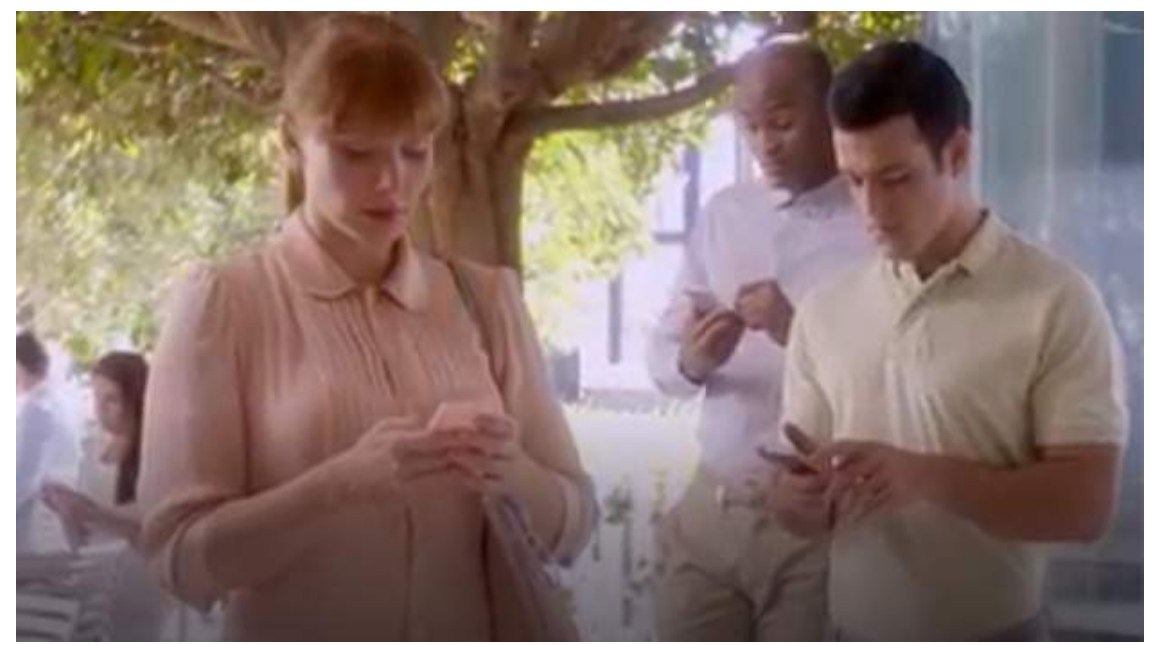

Picture 6. A Scene from Black Mirror's 'Nose Dive' Episode Displaying People Checking Their Scores

In picture 6, the scene displays people checking their scores from their mobile phones. Also in today's world, it is a general truth that mobile devices are indispensible parts of our daily lives and individuals spend some time with these devices. As it is stated in technology addiction process, the individuals become mono-types when the technology is used between 8 to 16 hours a day (Yengin \& Bayındır, 2019: 106-108). It can be assumed that one of the results of a gamified society is transforming the individuals into mono-types. In the given scene it is seen that how the game mechanics have involved in people's lives and everybody does similar activities in order to reach the similar targets. Gamification is a powerful tool and it should be taken under control in a proper way to activate healthier and wiser behaviours or give more happiness (Alter, 2017: 267). Like every powerful tool also gamification may cause better or worse outcomes depending on the designer or the design group.

\section{Conclusion}

In this study Black Mirror series third season's first episode titled as 'Nose Dive' which is broadcasted on Netflix digital platform is selected as a sample to evaluate gamification via game components, mechanics and dynamics. The futuristic point of view on how communication technologies will affect the social life in the future and the game elements used in the plot was effectual on choosing the episode. It also resembles that in some points gamification can be used as a tool for surveillance, governance and control of the society.

The analyzed subject is similar to the system called 'Sesame Credit', which China wants to make it mandatory and score all the citizens in 2020. In the Chinese system the individuals are rated according to their behaviours in real life in line with social rules and also with their social media activities. The gathered points provide individuals some advantages in their daily life or they come across with some restrictions due to their low scores. Similarly, in the Black Mirror episode, which is chosen as a sample, daily life is organized with game components, mechanics and dynamics. The plot of the episode is about a gamified community and Lacie Pound's daily life experiences in that fictional community. Lacie Pound, who is the main character, gives importance on behaving proper to game mechanics and tries to reach her desired score in order to get her desired dynamics like privileged life style and status. Adding game mechanics to a system is not enough for a participant to get involved in that process with an intrinsic motivation. The mechanics must be designed suitable to the dynamics. Similarly, after having been involved in unwanted situations, Lacie Pound realizes that she is getting away from her desired dynamics and her score is going down. As a result, she leaves the process due to seeing that her long-term effort is being wasted and at the end of the episode she is sent to a prison.

In Black Mirror series third season's first episode game components, mechanics and dynamics are determined and the episode displays a point of view on how gamification can be used to govern the society in the future. In the 'Nose Dive' episode, the mobile technologies we also use today are 
fictionalized in a way that they will involve in our lives more often and will become an indispensible part of social life. Gamification, which was first used in the literature in 2002 but has become more popular since 2010 , is being used in different fields like; education, health, marketing, and loyalty programmes thanks to improving technologies and digitalization. Since gamification notion is related with human psychology and wants the individual get involved into the process with intrinsic motivation, this makes it a powerful tool. Besides that while designing a gamified environment or event, it is necessary to behave within the framework of ethical rules. One of the main reasons of this truth is gamification is a kind of manipulation eventually. Questions like; to what extent it depends on individuals' will to live in a society which all the individuals have become mono-types and do they consciously approve this type of living style, etc. need to be discussed.

\section{References}

[1] Adler, A. (2012). İnsan tabiatını tanıma (9th ed.) (A. Yörükân, Trans.). İstanbul: Türkiye İş Bankası Kültür Yayınları.

[2] Akandere, M. (2013). Eğitici okul oyunları (4th ed.). Ankara: Nobel Yayıncılık.

[3] Alter, A. (2017). Karşı konulmaz: Bağımlılık yapıcı teknolojinin yükselişi ve bizim ona esir edişilimiz (D. İrengün, Trans.). İstanbul: Paloma Yayınevi.

[4] And, M. (2012). Oyun ve büyü: Türk kültüründe oyun kavramı (3rd ed.). İstanbul: Yapı Kredi Yayınları.

[5] Atabek, Ş.G. \& Atabek, Ü. (2007). Medya metinlerini çözümlemek: İçerik, göstergebilim ve söylem çözümleme yöntemleri. Ankara: Siyasal Kitabevi.

[6] Armstrong, B.M. \& Landers, N.R. (2018). Gamification of employee training and development. International Journal of Training and Development, 22(2), 1-8.

[7] Bayındır, B. (2017). Using emojis in WhatsApp group messaging throughout communication process. Communication and Technology Congress- CTC 2017. November 22-23, 2017, İstanbul Aydın University, 37-44. Doi: 10.7456/ctc_2017_07

[8] Bayraktar, Ö. (2015). Bir iletişim modeli olarak oyunlaştırma. İstanbul: Selis Kitaplar.

[9] Burke, B. (2014). Gamify: How gamification motivates people to do extraordinary things. New York: Bibliomotion Inc.

[10] Chayko, M. (2017). Superconnected: The internet, digital media, \& techno-social life. Los Angeles: Sage Publications.

[11] Chayko, M. (2018). Süperbağlantılı: İnternet, dijital medya ve tekno-sosyal hayat (B. Bayındır, D. Yengin \& T. Bayrak, Trans.). İstanbul: Der Yayınları.

[12] Caillois, R. (2001). Man, play and games (M. Barash, Trans.). Illinois: Glencoe Press.

[13] Çağlar, İ. \& Kılıç, S. (2011). Genel iletişim (4th ed.). Ankara: Nobel Yayıncılık.

[14] Deterding, S., Dixon D., Khaled, R., and Nacke, L. (2011). From game design element to gamefulness: Defining "gamification", Proceedings of the $15^{\text {th }}$ International Academic MindTreck Conference: Envisioning Future Media Environments, MindTreck'11, 28-30 September, Tampere, Finland, 2011, pp.9-15.

[15] Dijk, V.J. (2016). Ağ toplumu (Ö. Sakin, Trans.). İstanbul: Epsilon Yayıncılık.

[16] Doğan, A. (2013). Malatya çocuk oyunları. Malatya: Malatya Valiliği Malatya Kitaplığı Yayınları.

[17] Erdoğan, İ. (2003). Pozitivist metodoloji, bilimsel araştırma tasarımı, istatistiksel yöntemler, analiz ve yorum. Ankara: Erk Yayınevi.

[18] Erkek, H. (1999). Oyun içinde oyun. Ankara: T.C. Kültür Bakanlığı Yayınları.

[19] Extra Credits. (2015, Dec 16). Propaganda Games: Sesame Credit - The True Danger of Gamification [Video file]. Retrieved from https://www.youtube.com/watch?v=|HcTKWiZ8s|

[20] Gamification. (n.d.) In Gamified UK. Retrieved May 12, 2019 from http://www.gamified.uk/news/category/game-design/

[21] Güngör, N. (2016). İletişim: kuramlar, yaklaşımlar (3rd ed.). Ankara: Siyasal Kitabevi. 
[22] Huang, Z. (2015, Oct 9). All Chinese citizens now have a score based on how well we live, and mine sucks. Retrieved from https://qz.com/519737/all-chinese-citizens-now-have-ascore-based-on-how-well-we-live-and-mine-sucks/

[23] Huizinga, J. (2017). Homo ludens: Oyunun Toplumsal işlevi üzerine bir deneme (6th ed.) (M. A. Kılıçbay, Trans.). İstanbul: Ayrıntı Yayınları.

[24] Juul, J. (2005). Half real: Video games between real rules and fictional words. London: MIT Press.

[25] Kamasheva, A., V., Valeev, E., R., Yagudin, R., Kh., Maksimova, K., R. (2015). Usage of gamification theory for increase motivation of employees. Mediterranean Journal of Social Sciences, 6(1), 77-80.

[26] Marczewski, A. (2017). The ethics of gamification, XRDS crossroads. The ACM Magazine for Students, 24(1), 56-59.

[27] Mutlu, E. (1995). İletişim sözlüğü. (2nd ed.). Ankara: Ark Yayınevi.

[28] Oktay, M. (2002). Politikada halkla ilişkiler. İstanbul: Der Yayınları.

[29] Oskay, Ü. (2014). Kitle iletişiminin kültürel işlevleri: XIX. yüzyıldan günümüze kuramsal bir yaklaşım. İstanbul: İnkılâp Kitabevi.

[30] Oyunlaştırma. (n.d.). In Google Trends. Retrieved May 15, 2019 from https:/trends.google.com/trends/explore?q=\%2Fm\%2F0cm8xv9\&date=all

[31] Özel, A. \& Sert, Y.N. (2015). Dijital halkla ilişkiler kavram ve araçları. İstanbul: Derin Yayınları.

[32] Parlatır, I.., Gözaydın, N., Zülfikar, H., Aksu, T., Türkmen, S., \& Yılmaz, Y. (1998). Türkçe sözlük (9th ed.). Ankara: Türk Tarih Kurumu Basım Evi.

[33] Sezgin, S., Bozkurt, A., Yılmaz, A., E., \& Linden, V.N. (2018). Oyunlaştırma, eğitim ve kuramsal yaklaşımlar: Öğrenme süreçlerinde motivasyon, adanmışlık ve sürdürülebilirlik. Mehmet Akif Ersoy Üniversitesi Eğitim Fakültesi Dergisi, Sayı: 45, 169-189.

[34] Tutar, H. ve Yılmaz, K. (2010). Genel iletişim: Kavramlar ve modeller (7th ed.). Ankara: Seçkin Yayıncılık.

[35] Werbach, K. \& Hunter, D. (2012). For the win: How game thinking can revolutionize your business. Philadelphia: Wharton Digital Press.

[36] Yalçınkaya, T. (2004). Eğitici oyun ve oyuncak yapımı (2nd ed.). İstanbul: Esin Yayınları.

[37] Yengin, D. (2012). Dijital oyunlarda şiddet. İstanbul: Beta Basım Yayım Dağıtım A.Ş.

[38] Yengin, D. \& Bayındır, B. (2019). Dijital Bağımlı. In G.H. Karadağ (Ed.) Dijital Hastalıklar (pp. 85-115). İstanbul: Der Yayınları.

[39] Yılmaz, A.E. (2017). Oyunlaştırma: Herkes için oyunlaştırma (4th ed.). İstanbul: Abaküs Kitap Yayın Dağııım Hizmetleri.

[40] Yılmaz, A.E. (2018). Yeni nesil motivasyon: İş'te oyunlaştırma. İstanbul: Ceres Yayınları. 